Article

\title{
Sectoral Analysis of Factors Influencing Dividend Policy: Case of an Emerging Financial Market
}

\author{
Geetanjali Pinto ${ }^{1,2, *(\mathbb{D})}$ and Shailesh Rastogi ${ }^{3}$ \\ 1 SCRI, Symbiosis International (Deemed University), Pune 412 115, India \\ 2 ITM Business School Navi Mumbai, ITM Group of Institutions, Navi Mumbai 410 210, India \\ 3 Symbiosis Institute of Business Management Pune, Symbiosis International (Deemed University), \\ Pune 412 115, India \\ * Correspondence: geetanjalip@itm.edu; Tel.: +91-022-6226-7062
}

Received: 27 May 2019; Accepted: 22 June 2019; Published: 26 June 2019

\begin{abstract}
This study aims to determine whether a firm's dividends are influenced by the sector to which it belongs. This paper also examines the explanatory factors for dividends across individual sectors in India. This longitudinal study uses balanced data consisting of companies listed on the National Stock Exchange (NSE) of India for 12 years—from 2006 to 2017. Pooled ordinary least squares (POLSs) and fixed effects panel models are used in our estimation. We find that size, profitability, and interest coverage ratios have a significant positive relation to dividend policy. Furthermore, business risk and debt reveal a significantly negative relation with dividends. The findings on profitability support the free cash flow hypothesis for India. However, we also found that Indian companies prefer to follow a stable dividend policy. As a result of this, even firms with higher growth opportunities and lower cash flows continue to pay dividends. We also find evidence that dividend policies vary significantly across industrial sectors in India. The results of this study can be used by financial managers and policymakers in order to make appropriate dividend decisions. They can also help investors make portfolio selection decisions based on sectoral dividend paying behavior.
\end{abstract}

Keywords: dividend policy; emerging market; industrial sectors; NSE India; panel data

JEL Classification: C33; G11; G35

\section{Introduction}

All investors expect a certain amount of return on their investment for the risk taken. Firms can allocate profits to their stockholders either through dividends or share repurchases. Investors can get a return on their investment through dividends (current income). Alternatively, if a company has a lucrative investment opportunity available, it may not distribute its profits. The outlay in a profitable venture will also increase the value of a company, resulting in capital gains (future income) to investors. Theoretically, both dividend payout and retention lead to shareholder wealth maximization. Thus, as concluded by Miller and Modigliani (1961), investors should not differentiate among dividends and retaining profits. However, Miller and Modigliani's assumptions of a perfect capital market, no taxes, certainty, and fixed investment strategy does not really exist.

Certain studies consider that the dividend decision influences the value of a firm (Walter 1963), and is interlinked with the firm's investment policy. Researchers also theorize that generally, investors are risk-averse and give preference to receive certain dividends rather than uncertain capital gains, which are riskier. It is referred to as the "bird-in-hand" argument, as investors prefer current income rather than future income (Gordon 1963). Also, the tax treatment of dividends and capital gains is different. Furthermore, tax preference determines the stocks selected by investors, depending on the 
stocks' specific dividend policies. It is denoted as the "clientele effect." However, Allen et al. (2000) report that dividends are not used by managers to attract investor clientele.

The signaling theory by Solomon (1963) and Ross (1977) suggests that dividend policy gives information about a stock. Dividends can be distributed out of profits, and require the existence of free cash flows; hence, the payment of dividends provides a positive signal to investors (Bhattacharya 1979; Miller and Rock 1985). According to Jensen (1986), the agency cost of the free cash flow model predicts that companies with larger free cash flows tend to distribute higher dividends rather than investing in projects with a lower net present value (NPV). It also assumes that such firms also take a higher amount of debt, which involves the payment of fixed interest charges. The obligation on the part of the company to make timely payments of principal and interest will ensure that the company does not invest in less profitable investment opportunities, and thus helps in reducing agency cost.

Various factors influencing a firms' dividend policy have been evaluated by researchers. The outcome of these studies has not entirely resolved the controversies linked to dividend decision. Hence, it is not astonishing that "dividend controversy" has been listed by Brealey and Myers (2002) as one among ten of the most important unsolved corporate finance problems. Also, the determinants of dividend decision are not uniform across firms. Nevertheless, researchers have reported that determinants of dividends vary across countries and over different periods of time e.g., (Ramcharran 2001). Studies have also reported that variations in dividends across countries occur because of differences in economic policy for each country, including corporate governance policy (Mitton 2004; Sawicki 2009) and pertinent laws applicable (La Porta et al. 2000b; Sawicki 2009).

Emerging and developed markets also differ in many ways. Glen et al. (1995) report that dividends in emerging market firms are more volatile than U.S. firms. Aivazian et al. (2003b) find that country-specific factors have an impact in determining dividend policies in emerging markets. They have also reported that compared with U.S. firms, higher dividends are paid by emerging market firms, which itself is puzzling. Reddy and Rath (2005) have also reiterated that dividend behavior in emerging markets has not been evaluated extensively. Hence, it is necessary to evaluate the dividend paying behavior of emerging market firms in further detail.

Lintner (1956) postulates that sectors influence the dividend policy. This sectoral influence is mainly because firms belonging to a sector have similar earnings prospects, investment prospects, and accessibility of resources. As a result of these similarities, firms in the same sector have similar dividend policies (Michel 1979; Baker 1988; Dempsey et al. 1993). However, very limited studies have evaluated the variances in dividend policy behavior across sectors. Also, the economy has undergone multiple changes, thereby altering this relationship. Furthermore, these studies have focused on developed markets.

Considering the above facts, this paper contributes to the existing literature in two ways. Firstly, it provides insight into the dividend policy issue for an emerging market. India has developed as the fastest expanding major economy across the globe, and hence it is considered for the purpose of this study. It is attracting many major economies for strategic investments, owing to the presence of an immense variety of industries, investment prospects, and increasing integration into the global economy. Secondly, this study strives to bridge a significant gap in the existing literature by evaluating the dividend behavior across industrial sectors.

The remaining paper is organized as follows. Section 2 appraises the present literature, develops the hypotheses and also provides an ephemeral overview of the Indian economy and its implication on dividend-paying behavior; Section 3 defines the source of our data and the variables involved, and also lays down the construction, relevance, and validity of the tools and techniques used for empirical analysis; Section 4 presents and discusses the outcomes from the analysis of collected data; and Section 5 provides the summary and conclusion of the paper. 


\section{Review of Literature and Institutional Background}

Dividend policy is a crucial corporate finance decision, which is interrelated to financing and investing decision. The existing literature has identified various dividend policy determinants. However, researchers agree that there is no solitary description of the dividend-paying behavior of firms. In fact, the more we look at the dividend behavior of firms, the more it seems like an unresolved "dividend puzzle" (Black 1976). Ooi (2001) has also cited that although dividend payout is considered as a vital management decision, it continues to puzzle managers, researchers, and investors. The puzzle circles around the factors influencing the dividend payout and whether investors pay attention to dividends?

\subsection{Factors Affecting Dividend Policy}

Lintner (1956) has reported that managers give importance to the stability of dividends. They do not like to cut or omit dividends. Instead, companies generally set a target payout ratio and consider current years' earnings and dividend of the previous year as essential dividend policy determinants. Present as well as future earnings, the stability of earnings, and shareholders' needs are considered as essential factors for dividends by Indonesian firms (Baker and Powell 2012).

Al-Najjar and Kilincarslan (2017) have reported that publicly listed firms in Turkey generally adopt long-term payout ratios, and hence the stability of the dividends is followed (comparatively less than the developed markets of the U.S.). They also report that the concentration of ownership affects the target payout ratios. Mehar (2005) has stated that dividends are related positively to insider ownership and inversely to liquidity for Pakistan listed firms.

Kevin (1992) finds that a change in profitability does not influence the dividends of Indian companies, as they tend to follow a sticky dividend policy. Mahapatra and Sahu (1993) have found that Lintner's model finds no support in the Indian context. They establish that mainly cash flows and then the net earnings are essential for a dividend payout in India. However, Bhat and Pandey (1994) surveyed the finance directors of the Economic Times 250 top Indian firms, and found that dividend payment depends on present and future earnings, as well as preceding years' dividend per share. Hence, these findings explain that Lintner's model is applicable in India. Mishra and Narender (1996) also report similar findings for state-owned-enterprises in India. Pandey and Bhat (2007) have found that restricted monetary policy leads to a reduction in dividend payments. They also report that the previous two years' dividends and the current year's dividend are significant for a dividend payout in India. However, they report an instability of dividend policies and not much of a tendency of smoothing dividends in Indian companies.

Fama and French (2001) have reported that large firms with a high profitability and low investment opportunities tend to pay dividends, and vice versa. Hence profitability, investment opportunities, and size are the three important characteristics that enable the differentiation between dividend paying and non-paying firms in the United States. These findings are consistent with studies conducted in developed economies by (Fama and French 1999; Easterbrook 1984; Benito and Young 2003; Ferris et al. 2006; Renneboog and Trojanowski 2007; Von Eije and Megginson 2008).

In addition to profitability, investment opportunities, and size, Yarram (2015) reports that dividends of Australian firms are also positively related to corporate governance. Chowdhury et al. (2014) however, report that dividend payments by Chinese firms do not indicate future profitability, but demonstrate good corporate governance.

For profitability, investment opportunities, and size, Al-Najjar (2009) report similar findings for Jordan listed firms. However, they also find that debt is inversely related to cash dividends. Yusof and Ismail (2016) also report similar findings for listed companies in Malaysia. Additionally, they also state that profitability and liquidity significantly influence dividends for Malaysia.

Bhole and Mahakud (2005) have reported that the retention ratio has a positive relation with profit after tax, investment level, borrowing cost, and rate of growth for Indian firms, and has a 
negative association with borrowed funds, tax rate, and cost of equity. These results are similar to Auerbach (1982) and Bhole (2000).

Reddy and Rath (2005) have reported that more profitable companies, having lesser opportunities to invest with a larger size, are likely to distribute dividends in India. Subhash Kamat and Kamat (2013) have reported that for Indian companies, the tangibility of assets, size, and earnings are significant for determining payout policies. The results are consistent with (Fama and French 2001; DeAngelo et al. 2004; Denis and Osobov 2008).

Setia-Atmaja (2010) has found that firms controlled by families pay higher dividends because of the existence of a larger proportion of independent directors, for publicly listed Australian companies. Gul (1999) has reported that government ownership is positively associated with debt financing and dividends for Shanghai-listed companies.

Extending the Baker and Wurgler (2004) theory of catering incentive to increase and decrease in dividend payments, Li and Lie (2006) have reported that companies tend to pay more dividends if they are profitable and large, and have low past dividend yield, debt ratio, cash ratio, and price-to-book ratio. Baker et al. $(2007,2013)$ have reported that firm size, profitability, investment opportunities, and catering incentives are essential factors for Canadian firms. Tangjitprom (2013) finds the support of catering theory of dividend in Thailand.

\subsection{Factors Affecting Dividend Policy-A Comparison across the Globe}

La Porta et al. (2000a) compare the dividends for 33 countries across the world. They report that the dividend payout is higher in countries that have a stronger system of investor protection. However, in such countries, the payout is lower for those companies who have high growth opportunities. Ramcharran (2001) has examined the differences in dividend yields for twenty-one emerging market economies (including India) from 1992-1999. The study found that in countries with a higher country risk, firms tend to have lower dividend payouts to use cash flows for financing future growth opportunities.

Aivazian et al. (2003b) have compared the factors influencing the dividends of emerging market firms with U.S. firms. The results show that the level of dividends paid by emerging market companies is similar to U.S. firms, excluding Turkey (because of the imposition of legal constraints). Also, a similar relationship is found between dividend policy and the following three variables: profitability ratio, debt ratio, and the ratio of market to book value as revealed by U.S. firms. For both size coefficient and business risk coefficient, the signs are inconsistent. Further results have shown that in comparison with the United States, the companies in six emerging market countries with higher tangible assets tend to pay lesser dividends.

Mitton (2004) states that companies having strong corporate governance and lesser investment opportunities pay higher dividends, for firms across 19 countries. Brav et al. (2005) have compared dividend payout policies in the 21st century for the United States and Canadian public and private companies. They report that the existence of good investment avenues is essential for dividend decision. Taxes are not found to be significant.

Denis and Osobov (2008) have examined the dividend payout determinants for six countries with well-established financial markets, namely: the United States, Canada, the United Kingdom, Germany, France, and Japan. In line with (Fama and French 2001), this study also confirms that firm size, growth opportunities, and profitability are significant factors that help to determine dividends. The retained surplus to total equity ratio is also established as a significant factor of dividend policy.

Brockman and Unlu (2009) have found that there exists a positive relation between creditor rights and probability to pay dividends, as well as the amount of dividend payout for 52 countries across the globe. Abor and Bokpin (2010) have evaluated the dividend policy for 34 emerging markets, and report that investment opportunity and dividends have a significant negative relationship. Furthermore, profits and the market capitalization of stock also influence dividend decision. However, additional 
measures, namely, external financing, financial leverage, and debt finance, do not significantly impact the dividend payout.

Farooq and Jabbouri (2015) have found that dividends and cost of debt are negatively associated with each other for the Middle East and North African region (MENA) firms. They also report that this phenomenon is more prevalent in firms having higher information asymmetries.

\subsection{Dividend Policy and Industry Influence}

While selecting a payout policy, a firm considers various factors such as earnings, profitability, size, debt, cash flows, and many other economic factors as discussed above. Additionally, a firm also evaluates the payout policy of other firms in the same sector, before deciding its dividend policy. While a few past studies have evaluated the industrial sector's influence on dividend payout, there is no consensus.

Michel (1979) have evaluated twelve industries in the United States using the Kruskal-Wallis one-way analysis of variance. They have reported statistically significant variations in the dividend payouts for these sectors. Marsh and Merton (1987) also propose that firms detect industry practice before selecting a target dividend payout for themselves. However, its effect has not been tested explicitly by them. Baker (1988) has updated the study conducted by Michel. He also finds support for industry influence on dividends.

Pandey (2003) has studied the dividend payout for six industrial sectors of Malaysia. The author uses non-parametric, Kruskal-Wallis (K-W) one-way analysis of variance of ranks (Michel 1979; Scott and Martin 1975), and finds that the dividends of these companies differ across industrial sectors.

However, Baker et al. (2002) report that the company's industry type does not influence the manager's views in respect of dividends.

Mohamed et al. (2012) have suggested that the study of dividend policy can be widened by including an analysis across industries, and adding other characteristics that influence dividend policy.

\subsection{Institutional Background}

Major economic reforms in 1991 led the Indian economy towards economic liberalization and globalization. The major changes include the lowering of import tariffs and taxes, the deregulation of markets, and a rise in foreign investment. Also, since the formation of the Securities and Exchange Board of India (SEBI) in 1992, there has been an increase in the overall development, regulation, and supervision of the Indian stock market. As a result of significant improvements in the capital market regulations in India since the last two decades, companies can now issue shares using the book-building process, and raise funds through foreign capital. Indian companies thus have access to many alternative sources of finance, instead of relying on retained earnings. All of this has led to a change in their shareholding pattern. Accordingly, this will influence their dividend policy.

Furthermore, the Indian stock market consists of stocks covering the entire gamut-financial, industrial, and energy - thus providing exposure to a wide range of sectors. Another distinctiveness of the Indian stock market ${ }^{1}$ is that more than $55 \%$ of the equity market is held by promoters, thereby reducing the overall free float of the stock. In order to address this peculiarity, the SEBI mandated all listed companies to raise public shareholdings to $25 \%$ by mid-2013. In the framework of this transformed economic setting, the objective of this study is to evaluate the factors influencing the dividends of companies in India across sixteen industrial sectors.

1 Further details on Indian stock market are available under https://www.nseindia.com/. 


\section{Data and Methodology}

\subsection{Sample Selection}

The Indian stock market consists of two main stock exchanges, namely, the Bombay Stock Exchange (BSE) and the National Stock Exchange (NSE), apart from many other regional stock exchanges. Almost all of the significant Indian companies are listed on both these exchanges. We considered the data of all of the companies in NIFTY 500 NSE-index for the period of 2006 to 2017. The sample period was chosen to signify the current state of companies in India. NIFTY 500 index represents the top 500 companies listed on NSE based on full market capitalization. It represents $95.2 \%$ of the free float market capitalization of stocks listed on the NSE as of 31 March $2017^{2}$. The financial data of all of the companies were obtained from the Prowessdx database. The financial performance of all of the Indian companies were provided by the Centre for Monitoring Indian Economy (CMIE) in this database. It is the largest database, and the financial statements contained therein are standardized and do not suffer from any deliberate survival bias. Although data were extracted for all 500 companies, because of the absence of data for a few companies for entire time-period from 2006 onwards, the final analysis was done on 424 companies only. Outliers were also removed using a statistical three-sigma method. Hence, a balanced panel data of companies for 12-years, from 2006 to 2017, was used. Every company in CMIE is associated with an industry group. These industry groups have been formed by studying the number of companies in the clusters of industries, as per the detailed products and services classification ${ }^{3}$. Based on these industry group codes provided by CMIE, the 424 companies under selection have been grouped into sixteen sectors.

Total dividend divided by total assets was used to determine the dividend policy of a company, and is considered as the dependent variable in this study. The dependent variable, as well as the explanatory variables, were carefully chosen based on the literature review. Table 1 presents the number of companies considered under each industrial sector, along with the sector codes used in the paper and the sector-wise mean of the dividend/total assets (Div/TA).

Table 1. Summary of the number of companies considered under each industrial sector along with the sector codes and the sectoral mean of dividend/total assets (Div/TA). IT_-information technology; ITES-IT enabled service.

\begin{tabular}{|c|c|c|c|c|c|}
\hline Sr. No. & Sector & Sector Code & NIFTY 500 & Final Sample & Mean (Div/TA) \\
\hline 1 & Agro-based & AGRO & 13 & 12 & 0.0106 \\
\hline 2 & Mineral-based & MINING & 66 & 62 & 0.0173 \\
\hline 3 & Engineering & ENGG & 24 & 21 & 0.0198 \\
\hline 4 & Automobile and ancillary & AUTO & 27 & 24 & 0.0277 \\
\hline 5 & Power and fuel & POWER & 24 & 21 & 0.0160 \\
\hline 6 & Textile & TEXTILE & 13 & 13 & 0.0135 \\
\hline 7 & Drugs and pharmaceuticals & PHARMA & 30 & 28 & 0.0311 \\
\hline 8 & Consumer goods and appliances & CONSGDS & 39 & 32 & 0.0427 \\
\hline 9 & Other manufacturing & M-OTH & 32 & 32 & 0.0185 \\
\hline 10 & Entertainment, health, and tourism & MEHH & 25 & 18 & 0.0209 \\
\hline 11 & Trading/services (others) & S-OTHS & 38 & 21 & 0.0217 \\
\hline 12 & Construction and infrastructure & CONSTR & 29 & 22 & 0.0070 \\
\hline 13 & logistics & LOGISTICS & 21 & 19 & 0.0259 \\
\hline 14 & IT, ITES, and telecommunication & ITTELE & 30 & 26 & 0.0468 \\
\hline 15 & Banking & BANKING & 33 & 32 & 0.0015 \\
\hline \multirow[t]{2}{*}{16} & Other financial services & FINSER & 56 & 41 & 0.0194 \\
\hline & TOTAL & & 500 & 424 & \\
\hline
\end{tabular}

2 A detailed description of NIFTY 500 companies is available under https://www.nseindia.com/products/content/equities/ indices/nifty_500.htm.

3 The detailed definition of all variables is available under prowess dictionary at https://prowessiq.cmie.com. 


\subsection{Description of Variables and Hypothesis}

\subsubsection{Dependent Variable—Dividend/Total Assets (Div/TA)}

The following were used for determining the dividend payout policy of firms, out of four measures examined by (Aivazian et al. 2003b): dividend payout ratio, dividend yield, Div/TA, and dividend/book value per share; it was found that Div/TA is the most appropriate measure. The authors stated that the ratio of the dividend payout is extremely unstable and non-normal if the earnings reach near zero. Secondly, the dividend yield ratio uses market price, which is not in control of the management. Finally, the dividend to book value per share is prone to more misrepresentations, as it depends on the net worth of the company, which includes free reserves and can be easily distorted by companies. Compared to that, the total assets are less likely to be inaccurate (Aivazian et al. 2003b). Hence, this study also uses the total Div/TA as the dependent variable, and is referred to as dividend policy or payout policy hereafter.

\subsubsection{Explanatory Variables}

These are constructed on the theoretical framework of (Aivazian et al. 2003b) and an extensive literature review conducted herein. Apart from the sector, the remaining 12 explanatory variables have been broadly divided into the following three measures: operating measures (5), debt measures (3), and summary measures (4).

Sector. The Nifty 500 companies have been classified into 16 sectors. Classification into these 16 sectors is based on the CMIE classification of industry groups, as discussed in the previous sub-section. On the basis of the literature review conducted in the previous section, it is hypothesized that dividend policy differs significantly across industrial sectors.

Apart from the three operating measures as defined by (Aivazian et al. 2003b) - tangibility, business risk, and scale of operations (log of sales) — this study also considers two more operating measures-operating profit and size (log of market capitalization). The three debt measures include debt ratio, interest coverage ratio, and current ratio. Summary measures are further sub-divided into profitability, growth, and liquidity. To measure profitability, in addition to the return on equity (ROE), this study also considers the return on investment (ROI), following Reddy and Rath (2005). Mehmood et al. (2019) have also used both accounting measures, ROE and ROI, to measure profitability. Price to book value is used as a proxy for growth measure. Cash flow per share is used to measure liquidity, following Bhat and Pandey (1994) and Mohamed et al. (2012).

Table 2 defines each of these explanatory variables, now referred to as factors influencing dividend payout policy, and gives the nature of the relation expected with dividend payout policy.

\subsection{Model Specifications}

Firstly, we analyzed whether the dividend policy for the NSE-listed companies varies across sectors. We used a one-way analysis of variance test to analyze whether there are any statistically significant variations between the means of three or more independent (unrelated) groups. This technique tests the null hypothesis that the mean values of dividend policy are the same for all sectors. The null hypothesis is rejected if the calculated F statistics is greater than F critical value, or if the $p$-value is less than $\propto$, where $\propto$ denotes the level of significance.

The study then uses the panel data techniques to develop a model establishing a relation between the dividend policy and the explanatory factors. Hsiao (2003) has highlighted that using panel data sets for research provides researchers with more advantages compared with using conventional cross-sectional or time-series data sets, for example (Hsiao 1985, 1995; Hsiao and Sun 2000). 
Table 2. Description of variables with expected signs. ROE—return on equity; $\mathrm{P} / \mathrm{B}$ — the price-to-book value.

\begin{tabular}{|c|c|c|c|}
\hline Variable Name & Definition & Symbol & Expected Relationship \\
\hline Dividend policy & Total dividend paid divided by total assets & Div/TA & \\
\hline \multicolumn{4}{|l|}{ A. Operating measures } \\
\hline Tangibility & (Total assets minus current assets) divided by total assets & Tangibility & + \\
\hline Business risk & $\begin{array}{l}\text { Standard deviation of return on investment (ROI; lagged } \\
\text { three years) }\end{array}$ & BusRisk & - \\
\hline Scale of Operations & Natural logarithm of sales in local currency & LgSales & + \\
\hline Scale of Operations & Natural logarithm of market capitalization in local currency & LgMCap & + \\
\hline Operating profit & Earnings before interest and tax (EBIT) divided by total sales & OpProfit & + \\
\hline \multicolumn{4}{|l|}{ B. Debt measures } \\
\hline Debt ratio & Long term debt divided by total assets & DebtRatio & - \\
\hline Interest coverage ratio & EBIT divided by interest & IntCover & + \\
\hline Current ratio & Current assets divided by current liabilities & CurRatio & + \\
\hline \multicolumn{4}{|l|}{$\begin{array}{l}\text { C. Summary measures } \\
\text { i. Profitability }\end{array}$} \\
\hline Return on Equity & $\begin{array}{l}\text { Net profit after tax (NPAT) divided by net worth (where net } \\
\text { worth = equity share capital + reserves and surplus) }\end{array}$ & ROE & + \\
\hline Return on Investment & $\begin{array}{l}\text { EBIT divided by capital employed }(\mathrm{CE} ; \mathrm{CE}=\text { net worth }+ \\
\text { long term debt) }\end{array}$ & ROI & + \\
\hline $\begin{array}{l}\text { ii. Growth measure } \\
\text { price to book value ratio }\end{array}$ & $\begin{array}{l}\text { Market price per share divided by book value at the end of } \\
\text { the year }\end{array}$ & $\mathrm{P} / \mathrm{B}$ & - \\
\hline \multicolumn{4}{|l|}{ iii. Liquidity measure } \\
\hline Cash flow per share & $\begin{array}{l}\text { Net cash flow from operating activities divided by the } \\
\text { number of equity shares outstanding }\end{array}$ & CFPS & $+/-$ \\
\hline
\end{tabular}

The relation between dividend policy and the factors affecting it for selected NIFTY 500 companies and for each of the sectors is expressed in the form of an empirical model, as follows:

$$
\frac{D i v i, t}{T A i, t}=\propto i+\sum_{j=1}^{n} \beta i, j X i, j, t+\varepsilon i, t
$$

where $i=1, \ldots, N$, where $N$ is the number of cross-sectional units $=16$ sectors, $t=1, \ldots, T$, where $T$ is the time period $=12$ years and $j=1, \ldots, n$, and where $n$ is the number of explanatory variables $=12$ (Hill et al. 2007). $X_{i, j, t}$ is the explanatory variable $j$ for firm $i$ at time $t, \beta i, j$ is the slope for explanatory variable $j$ for sector $i, \varepsilon_{i, t}$ is the random error term for sector $i$ at time $t, D i v_{i, t} / T A_{i, t}$ is dividend-to-total asset ratio subscripted for sector $i$ at time $t$, and $\alpha_{i}$ is the intercept.

Table 2 summarizes the dependent and explanatory variables, which form part of the empirical model expressed in Equation (1). For some companies, the data for LgSales, OpProfit, the price-to-book value $(\mathrm{P} / \mathrm{B})$, and $\mathrm{CFPS}$ are not available, hence the regression equation is estimated with the remaining variables, as the absence of this data limits the sample size of these sectors.

The major benefit of panel data is that it improves the efficiency of the econometric estimation by giving researchers more data points, which increases the degrees of freedom and reduces collinearity between explanatory variables (Gujarati 2009). Hence, this study uses the panel data technique, which will enable the maximum utilization of data by considering both cross-sectional and time-series data.

There are four basic models available in the panel data model, namely: pooled ordinary least squares (POLS), fixed effect model (FEM), random effect model (REM), and Seemingly Unrelated Regression Equations (SUR) model (Adkins 2010). For determining the most suitable panel data model, panel diagnostic tests are available in GRETL (Baiocchi and Distaso 2003). The first-panel diagnostic test being F-statistics. It suggests that if the $p$-value is less than alpha, then the null hypothesis is rejected, and FEM is more suitable than the POLS model. Secondly, the Breusch-Pagan test helps to determine whether POLS or REM is applicable. It suggests that if the $p$-value is less than alpha, then the null hypothesis is rejected, and REM is more suitable than the POLS model. If both the F-statistics and Breusch-Pagan test are found to be positive, then finally, the (Hausman 1978) test is used for determining whether FEM or REM is suitable for estimation. The SUR model is used to 
estimate panel data models that have large time periods and a small number of cross-sectional units (Adkins 2010). Using these test results, we determine the appropriate model to be used for estimating the regression equation.

\title{
4. Empirical Results and Discussion
}

\subsection{Discussion on Consolidated Regression}

In this sub-section, we present our panel regression results, which identify the factors influencing the dividend policy for selected NSE companies. As discussed in the methodology section, the panel diagnostic test results are utilized to determine the appropriate panel data model. The results in Table 3 reveal that the $p$-value of F-statistics is 0.935 which is $>\propto$ (i.e., 0.05 ), hence we cannot reject the null. This suggests that POLS technique is more suitable than FEM (Adkins 2010; Cottrell and Lucchetti 2017). Hence, the findings are reported based on the POLS regression estimate.

Table 3. Consolidated (NIFTY 500) panel regression.

\begin{tabular}{|c|c|c|c|}
\hline Independent Variable & & Coefficients & \\
\hline Constant & 0.001 & $(0.698)$ & \\
\hline Tangibility & 0.000 & $(0.981)$ & \\
\hline BusRisk & -0.011 & $(0.000)$ & $* * *$ \\
\hline LgSales & 0.001 & $(0.000)$ & $* * *$ \\
\hline LgMCap & 0.000 & $(0.034)$ & $* *$ \\
\hline OpProfit & 0.000 & $(0.463)$ & \\
\hline DebtRatio & -0.036 & $(0.000)$ & $* * *$ \\
\hline IntCover & 0.000 & $(0.020)$ & $* *$ \\
\hline CurRatio & 0.000 & $(0.000)$ & $* * *$ \\
\hline $\mathrm{ROE}$ & 0.001 & $(0.004)$ & $* * *$ \\
\hline ROI & 0.020 & $(0.000)$ & $* * *$ \\
\hline $\mathrm{P} / \mathrm{B}$ & 0.001 & $(0.000)$ & $* * *$ \\
\hline CFPS & -0.000 & $(0.004)$ & $* * *$ \\
\hline \multicolumn{2}{|c|}{ F-Statistics: 0.894 (0.935) } & \multicolumn{2}{|c|}{ Breusch-Pagan test: $2.392(0.122)$} \\
\hline \multicolumn{2}{|c|}{ Hausman test: $22.312(0.034)$} & \multicolumn{2}{|c|}{ Appropriate model: POLS } \\
\hline \multicolumn{2}{|c|}{ Durbin Watson = 1.845} & \multicolumn{2}{|c|}{ Overall R-square $=0.147$} \\
\hline \multicolumn{2}{|c|}{ Number of Companies $(\mathrm{N})=424$} & \multicolumn{2}{|c|}{ Number of years $(\mathrm{T})=12$} \\
\hline \multicolumn{4}{|c|}{ No. of observations (balanced) $=5088$} \\
\hline
\end{tabular}

\begin{abstract}
Notes: Regression coefficients are estimated using pooled ordinary least squares. Dividends divided by total assets is the dependent variable. The independent variables are as follows. Tangibility is total assets minus current assets divided by total assets. BusRisk is the standard deviation of ROI (lagged three years). LgSales is the natural logarithm of sales in local currency. LgMCap is the natural logarithm of market capitalization in local currency. OpProfit is EBIT divided by total sales. DebtRatio is the long-term debt divided by total assets. IntCover is EBIT divided by interest. CurRatio is current assets divided by current liabilities. ROE is NPAT divided by net worth. ROI is EBIT divided by CE. $\mathrm{P} / \mathrm{B}$ is the market price per share divided by book value per share at the end of the year. CFPS is net cash flow from operating activities divided by the number of equity shares outstanding. The $t$-statistics are given in parentheses. ${ }^{* * *}$ Significant at the $1 \%$ level; ${ }^{* *}$ significant at the $5 \%$ level. POLS- pooled ordinary least squares.
\end{abstract}

The results in Table 3 reveal that scale of operations, interest coverage ratio, current ratio, ROE, $\mathrm{ROI}$, and $\mathrm{P} / \mathrm{B}$ ratio have a positive relation to the dividend policy. This suggests that companies with the larger scale of operations, higher interest coverage ratios, current ratio, profitability and growth opportunities are likely to pay higher dividends. However, there is evidence that business risk, debt ratio, and CFPS have a negative relation with dividend policy for NSE firms. This implies that firms with higher business risk, debt levels, and cash flows are likely to pay lower dividends.

The results for the scale of operations, interest coverage ratio, current ratio, ROE, ROI, business risk, debt ratio, and CFPS, except for the P/B ratio, are in line with our hypotheses. We had expected that companies having more growth opportunities would most likely pay lower dividends, but for our 
sample, the $\mathrm{P} / \mathrm{B}$ ratio had a marginal positive coefficient. For the remaining variables-tangibility of assets and operating profit—we found no significant relationship with dividend policy.

\subsection{Sectoral Influence on Dividend Policy}

Table 1 shows that the highest Div/TA ratio is of the information technology (IT), IT enabled service (ITES), and telecommunication (ITTEL)-sector (0.0468), followed by the consumer goods and appliances (CONSGDS)-sector (0.0427). The logistics (LOGISTICS), automobile and ancillary (AUTO), and drugs and pharmaceuticals (PHARMA) sectors have a mean Div/TA ratio in the range of 0.025-0.03. The banking (BANKING)-sector shows the lowest ratio (0.0015), followed by the construction and infrastructure (CONSTR)-sector (0.007) and agro-based (AGRO)-sector (0.0106).

The one-way analysis of variance test was used for determining the relation between dividend policy and sectors. These results (not reported here) show that the means of the dividend policy of each of the 16 sectors vary significantly. The $p$-value of $0.000<\propto$ (i.e., 0.05 ), hence we reject the null hypothesis. This signifies that the dividend policy significantly differs across sectors. Thus, the industrial sector influences the dividend policy in India.

\subsection{Discussion on Sectoral Regression}

In this sub-section, we present our panel regression results to detect the sector-wise factors influencing dividend policy. As discussed in the methodology section, the panel diagnostic test results are used to determine the panel data model favorable for each sector. As seen in Appendix A, the $p$-value of the F-statistics for the AGRO sector is 0.016 , which is $<\propto$ (i.e., 0.05), hence we reject the null. This recommends that the FEM technique is more suitable than POLS for estimating the factors influencing the dividend policy in the AGRO-sector. The results reveal that for all other sectors, the $p$-value of F-statistics is greater than 0.05 . Thus, for the remaining fifteen sectors, the POLS model is suitable. Accordingly, based on the panel diagnostic test results (Baiocchi and Distaso 2003), we report the findings using the FEM regression estimates for the AGRO-sector, and the POLS regression estimate for the remaining 15 sectors.

The overall $\mathrm{R}^{2}$ is the highest for the AUTO-sector (0.82) and lowest for PHARMA-sector (0.12). For the LOGISTICS, textile (TEXTILE), and AGRO sectors, $R^{2}$ ranges between $0.61-0.67$. The overall $\mathrm{R}^{2}$ for the power and fuel (POWER), other financial services (FINSER), and ITTEL sectors lies between 0.50-0.55. Also, for the BANKING, other manufacturing (M-OTH), and CONSGDS sectors, it is between 0.44-0.46. For the remaining sectors-CONSTR, trading/services (S-OTHS), engineering (ENGG), entertainment, health, and tourism (MEHH), and mining-based (MINING) - the overall $\mathrm{R}^{2}$ value ranges between $0.31-0.38$. These overall $R^{2}$ values in the range of $0.31-0.82$ suggest a good indication regarding the explanatory power of the individual sector panel regressions.

\subsubsection{Operating Measures}

The sector-wise panel regression in Appendix A reveals a strong positive relation between the tangibility of assets (TANG) and the dividend policy for firms from the AGRO, MINING, ENGG, TEXTILE, CONSGDS, CONSTR, and LOGIS sectors. This implies that the companies in these sectors tend to pay dividends if they have higher TANG, in line with past studies e.g., (Aivazian et al. 2003a; DeAngelo et al. 2004; Denis and Osobov 2008; Subhash Kamat and Kamat 2013). However, TANG has an inverse relation with dividend policy for firms of the BANKING-sector.

The business risk variable displays inconsistent signs. Although we find that it is inversely associated with dividends in the CONSTR, BANKING, and S-OTHS sectors, their importance is opposite in the ITTEL and FINSER sectors. This variable is found to be insignificant in the remaining sectors. A possible explanation for this is that all sectors are exposed to risks that are pertinent to their line of business and sector-specific regulations in which they function. Aivazian et al. 2003a also report mixed results for the business risk variable when comparing the dividend policy of the United States with emerging market firms. 
For the scale of operations as measured by the log of sales (LgSales), although we expected a positive association with the dividend policy, the findings suggest that none of the sectors are significantly influenced by it. The LgSales variable is not considered for panel regression estimation in the BANKING and FINSER sectors, because of the difference in revenue parameters. The log of market capitalization (LgMCap) is used to evaluate the influence of the size on the dividend payout for these sectors. Information on LgMCap was not available for all companies of the TEXTILE-sector, hence it is excluded for the panel regression estimation of this sector. The results show a positive association of LgMCap with dividends of the ENGG, AUTO, PHARMA, CONSGD, M-OTH, MEHH, and CONSTR sectors. The positive impact indicates that firms from these sectors that are greater in size are likely to pay more dividends. This is likely, as such firms can access capital markets without difficulty, thereby having lesser dependence on retained surplus, thus allowing them to distribute more dividends (Mohamed et al. 2012; Al-Najjar and Kilincarslan 2017).

Furthermore, Appendix A shows that operating profits have a positive effect on the payout policy for the MINING, POWER, and MEHH sectors. This means that the sectors reporting a poor operating income will pay lower dividends, consistent with ( $\mathrm{Li}$ and Lie 2006). However, the results are opposite for the AUTO, M-OTH, and ITTEL sectors. A possible explanation for this could be that the firms of these sectors continue to pay dividends, although the operating profits are low, as they prefer to distribute stable dividends, as reported by (Bhat and Pandey 1994) for Indian firms.

The operating measures are used to evaluate the impact of the size/scale of operations. Many studies as discussed in the literature review have reported that larger size firms are likely to pay higher dividends. We also find that either a higher tangibility of assets/market capitalization/operating profits or lower business risk positively influences dividends. At least one or more operating measures are found to be significant for the consolidated sample and for each of the individual sectors.

\subsubsection{Debt Measures}

The results reveal a negative association between debt and dividend policy for the AGRO, MINING, POWER, MEHH, CONSTR, LOGISTICS, ITTEL, and FINSER sectors. This implies that sectors with high debt levels appear to pay low dividends (Aivazian et al. 2003b; Li and Lie 2006; Al-Najjar and Kilincarslan 2017). However, for the BANKING-sector, the results depict a significant positive effect. A possible explanation is that the easy availability of external sources of funds for banks enables them to pay higher dividends and rely less on retentions (Auerbach 1982; Jensen 1986; Bhole 2000; Bhole and Mahakud 2005). Furthermore, for the remaining sectors, debt levels do not significantly influence dividends. This means that the dividend policy of the ENGG, AUTO, TEXTILE, PHARMA, CONSGDS, M-OTH, and S-OTH sectors do not depend on the debt levels, as found by (Abor and Bokpin 2010; Farooq and Jabbouri 2015; Yusof and Ismail 2016).

Denis and Osobov (2008) have observed that a lower interest coverage ratio leads to the abandonment of dividend payout. We also show that the interest coverage ratio positively influences the payout policy for the TEXTILE, LOGISTICS, and BANKING sectors. However, for the remaining sectors, the results show no significant impact.

Similar to the consolidated panel estimates, the sector-wise panel results also reveal that the current ratio and dividend policy are significantly positively associated in the AGRO, MINING, ENGG, AUTO, POWER, MEHH, CONSTR, and LOGISTICS sectors. This implies that higher short-term liquidity enables these sectors to pay higher dividends.

Overall, we found that a higher interest coverage ratio and current ratio, and lower debt ratios tend to influence the dividends of Indian firms. Except for the PHARMA, CONSGDS, M-OTH and S-OTHS sectors, either of the debt measures were found to be significant.

\subsubsection{Summary Measures}

We found another positive relationship between profitability and dividend policy. Although this study uses two variables (ROE and ROI) to measure profitability, we found a significant positive impact 
of ROI in 14 sectors, but ROE shows a significant positive impact in three sectors only (MEHH, S-OTH, and LOGISTICS). In the MEHH and S-OTH sectors, the ROI variable is found to be insignificant. The analysis thus indicates that firms having a higher profitability in these sectors are likely to distribute higher dividends. These findings support Jensen (1986)'s free cash flow hypothesis, and are consistent with prior studies e.g., (Fama and French 2001; Benito and Young 2003; Aivazian et al. 2003b; DeAngelo et al. 2004; Mitton 2004; Reddy and Rath 2005; Baker et al. 2007, 2013; Bostanci et al. 2018). However, the profitability measure may differ for each sector.

We found that the price-to-book value $(\mathrm{P} / \mathrm{B})$ ratio is significantly positively related to the dividend policy for four sectors only (AUTO, TEXTILE, LOGISTICS, and FINSER). This is consistent with studies such as (Nizar Al-Malkawi 2007; Foroghi et al. 2011; Al-Shubiri 2011; Imran 2011; Yusof and Ismail 2016). However, it is significantly negatively related to the dividend policy for the BANKING-sector only. This is in line with our expectation, and also in line with prior studies (Auerbach 1982; Easterbrook 1984; Jensen 1986; La Porta et al. 2000b; Bhole 2000; Fama and French 2001; Benito and Young 2003; Mitton 2004; Reddy and Rath 2005; Bhole and Mahakud 2005; $\mathrm{Li}$ and Lie 2006; Ferris et al. 2006). Information on the P/B ratio was not available for all companies of the AGRO and PHARMA sector, hence it was excluded for the panel regression estimation of these sectors.

As anticipated, we found that liquidity will be either positively or negatively related to dividend policy, depending upon the industry. Our panel regression estimates show that there is a significant positive impact of CFPS on payout policy for the CONSGDS and S-OTH sectors. This signifies that firms with a higher liquidity are likely to pay higher dividends in these sectors. However, results are opposite for the MINING, AUTO, and M-OTH sectors. This implies that companies in these sectors continuously distribute dividends, although they have fewer cash flows. Bhat and Pandey (1994) have found that in India, as companies prefer to follow a stable dividend policy, the availability of cash is not a significant factor for evaluating payout policy. The agency theory also explains the payment of dividends through borrowed funds in case of the non-availability of cash. Information on the P/B ratio was not available for all companies of the AGRO, TEXTILE, and PHARMA sector, hence it was excluded for the panel regression estimation of these sectors.

Generally, we can conclude that the factors influencing dividend policy differ across sectors in India. For the LOGISTICS sector firms, tangibility, LgMCap, debt ratio, interest coverage ratio, current ratio, $\mathrm{ROE}, \mathrm{ROI}$, and $\mathrm{P} / \mathrm{B}$ ratio significantly impact the dividend policy. For the AUTO-sector firms, operating profit, LgMCap, current ratio, ROE, ROI, P/B ratio, and CFPS significantly influence payout policy. For the BANKING-sector, tangibility, business risk, debt ratio, interest coverage ratio, current ratio, ROI, and P/B ratio significantly influence the dividend policy. For the MINING-sector, firms, tangibility, operating profit, debt ratio, current ratio, ROI, and CFPS influence the dividends. In the CONSTR sector companies, tangibility, business risk, LgMCap, debt ratio, current ratio, and ROI are important dividend determinants. For the AGRO and ENGG sectors, tangibility, current ratio, and ROI influence the firms' dividend policy. Additionally, the debt ratio is an important dividend policy determinant in the AGRO sector, and LgMCap in the ENGG sector. In the CONSGDS sector, tangibility, LgMCap, ROE, ROI, and CFPS influence the dividend decision, whereas for the M-OTH sector, operating profit plays an important role instead of ROE for determining the dividend policy. For the MEHH sector, the operating profit, LgMCap, debt ratio, current ratio, and ROE influence the dividends. In the POWER sector, only four factors-operating profit, debt ratio, current ratio, and ROI-are important dividend policy determinants. For the TEXTILE sector, also only four factors-tangibility, interest coverage ratio, $\mathrm{ROI}$, and $\mathrm{P} / \mathrm{B}$ ratio significantly influence the payout policy. Moreover, for the S-OTHS-sector, only three factors (business risk, ROE, and CFPS), and PHARMA-sector, only two factors (LgMCap and ROI), significantly influence the payout policy. A possible explanation could be that macro-economic factors rather than firm-specific factors influence the payout policies of these sectors. Lastly, the sectoral regression results show that the scale of operations as measured by LgSales does not significantly influence the payout policy for any of the sectors in India. 


\section{Overall Summary and Conclusions}

This study offers fresh evidence on the key determinants of the dividend policy for an emerging market economy using financial data for Indian-listed firms. This study uses pooled OLS and fixed effect panel data models to examine the factors affecting dividends.

Our findings suggest that in general, firms with a larger size, higher interest coverage ratio and profitability, and low business risk and debt are likely to distribute higher dividends in India. The results on profitability indicate the applicability of the free cash flow hypothesis in India. However, the findings also reveal that companies with more growth opportunities and lower cash flows also continue to distribute dividends. We attribute this to the condition that Indian firms prefer to maintain stability in dividend policy, such that availability of investment opportunities and the non-availability of cash is insignificant for determining dividend policy.

We also scrutinize the variation in dividend policy across sixteen industrial sectors in India. The results suggest that the factors influencing dividend policy differ across sectors. The sector-wise results show that size (either tangibility/LgMCap) is found to significantly influence payout policy in all sectors except AUTO and POWER. Also, either one or more of the debt measures (debt ratio/interest coverage/current ratio) are also found to be significant in all of the sectors, excluding PHARMA, CONSGDS, M-OTHS, and S-OTHS. For summary measures, we found that profitability has the same positive relation for all industrial sectors. Whereas growth measure and liquidity measure do not significantly influence the dividend policy in eleven sectors. Moreover, for the remaining sectors, the signs are mixed.

Hence, sectoral results suggest that there are no uniform set of factors influencing dividend policy for all sectors. Although a "one-size fits all" technique is unsuitable for evaluating the factors, our finding suggests that the dividend policies of firms across sectors are generally sensitive to size, debt, and profitability. Preferences of one variable over another may occur as a result of firm-level and sector-level effects on dividend policy recognized in past empirical research (such as Sawicki 2003). Furthermore, these findings provide unbiassed guidelines to investors regarding the factors that influence the dividend policies of Indian companies.

Lastly, the findings reveal that the majority of the theories on dividend policy that are classically based on developed markets can be applied to emerging market countries such as India, as most of the characteristics found to important in determining dividend policies in India are consistent with those established in developed economies. However, further research is needed for investigating the influence of other firm-specific characteristics, such as corporate governance policies and investor demographics, which are not included in this study.

Author Contributions: Conceptualization, G.P. and S.R.; data curation, G.P.; formal analysis, G.P. and S.R.; investigation, G.P.; methodology, G.P. and S.R.; resources, G.P. and S.R.; software, G.P.; supervision, S.R.; validation, G.P. and S.R.; visualization, G.P.; writing (original draft), G.P.; writing (review and editing), S.R.

Funding: This research received no external funding.

Conflicts of Interest: The authors declare no conflict of interest. 
Appendix A

Table A1. Sector-wise panel regression.

\begin{tabular}{|c|c|c|c|c|c|c|c|c|c|c|c|c|c|c|c|c|c|c|}
\hline Sector & Constant & Tangibility & BusRisk & LgSales & LgMCap & OpProfit & DebtRatio & IntCover & CurRatio & ROE & ROI & $\mathrm{P} / \mathrm{B}$ & CFPS & $\begin{array}{l}\text { No. of Obs. } \\
\text { (Balanced) }\end{array}$ & $\begin{array}{c}\begin{array}{c}\text { Overall R } \\
\text { Square }\end{array} \\
\end{array}$ & F-Statistics & $\begin{array}{c}\text { Breusch-Pagan } \\
\text { Test }\end{array}$ & $\begin{array}{c}\text { Hausman } \\
p \text {-Value }\end{array}$ \\
\hline AGRO & $\begin{array}{c}0.022 \\
(0.128)\end{array}$ & $\begin{array}{c}0.017 \\
(0.005) * * *\end{array}$ & $\begin{array}{c}0.024 \\
(0.204)\end{array}$ & $\begin{array}{c}-0.003 \\
(0.034)^{* *}\end{array}$ & $\begin{array}{c}0.001 \\
(0.382)\end{array}$ & $\begin{array}{c}0.018 \\
(0.101)\end{array}$ & $\begin{array}{c}-0.036 \\
(0.000) * * *\end{array}$ & $\begin{array}{c}0.000 \\
(0.364)\end{array}$ & $\begin{array}{c}0.001 \\
(0.073) *\end{array}$ & $\begin{array}{l}-0.013 \\
-0.158\end{array}$ & $\begin{array}{c}0.065 \\
(0.000)^{* * *}\end{array}$ & $\mathrm{~N} / \mathrm{A}$ & $\mathrm{N} / \mathrm{A}$ & 144 & 0.674 & $\begin{array}{c}2.237 \\
(0.016)\end{array}$ & $\begin{array}{c}1.116 \\
(0.291)\end{array}$ & $\begin{array}{l}9.200 \\
(0.513)\end{array}$ \\
\hline MINING & $\begin{array}{l}-0.007 \\
(0.221)\end{array}$ & $\begin{array}{c}0.012 \\
(0.003)^{* * *}\end{array}$ & $\begin{array}{l}-0.013 \\
(0.396)\end{array}$ & $\begin{array}{c}0.001 \\
(0.151)\end{array}$ & $\begin{array}{c}0.000 \\
(0.341)\end{array}$ & $\begin{array}{c}0.017 \\
(0.000)^{* * *}\end{array}$ & $\begin{array}{c}-0.025 \\
(0.000) * * * \\
\end{array}$ & $\begin{array}{c}0.000 \\
(0.192) \\
\end{array}$ & $\begin{array}{c}0.001 \\
(0.005) * * *\end{array}$ & $\begin{array}{c}0.000 \\
(0.814)\end{array}$ & $\begin{array}{c}0.058 \\
(0.000)^{* * *}\end{array}$ & $\begin{array}{c}0.000 \\
(0.567)\end{array}$ & $\begin{array}{c}-0.000 \\
(0.002)^{* * * *}\end{array}$ & 744 & 0.386 & $\begin{array}{l}1.245 \\
(0.106)\end{array}$ & $\begin{array}{l}1.282 \\
(0.258)\end{array}$ & $\begin{array}{l}30.697 \\
(0.002)\end{array}$ \\
\hline ENGG & $\begin{array}{l}-0.011 \\
(0.236)\end{array}$ & $\begin{array}{c}0.046 \\
(0.000)^{* * *}\end{array}$ & $\begin{array}{l}-0.014 \\
(0.558)\end{array}$ & $\begin{array}{c}-0.004 \\
(0.001)^{* * *}\end{array}$ & $\begin{array}{c}0.003 \\
(0.002)^{* * *}\end{array}$ & $\begin{array}{l}-0.007 \\
(0.505)\end{array}$ & $\begin{array}{l}-0.024 \\
(0.153)\end{array}$ & $\begin{array}{c}0.000 \\
(0.598)\end{array}$ & $\begin{array}{c}0.005 \\
(0.008)^{* * *}\end{array}$ & $\begin{array}{l}-0.001 \\
(0.208)\end{array}$ & $\begin{array}{c}0.073 \\
(0.000)^{* * *}\end{array}$ & $\begin{array}{c}0.000 \\
(0.856)\end{array}$ & $\begin{array}{c}0.000 \\
(0.829) \\
\end{array}$ & 252 & 0.334 & $\begin{array}{c}1.053 \\
(0.401)\end{array}$ & $\begin{array}{c}0.007 \\
(0.935)\end{array}$ & $\begin{array}{l}17.269 \\
(0.140)\end{array}$ \\
\hline AUTO & $\begin{array}{c}0.047 \\
(0.001)^{* * *}\end{array}$ & $\begin{array}{c}0.017 \\
(0.135) \\
\end{array}$ & $\begin{array}{l}-0.018 \\
(0.658)\end{array}$ & $\begin{array}{c}0.000 \\
(0.936)\end{array}$ & $\begin{array}{c}0.001 \\
(0.029)^{* *}\end{array}$ & $\begin{array}{c}-0.125 \\
(0.000)^{* * *}\end{array}$ & $\begin{array}{c}0.014 \\
(0.202) \\
\end{array}$ & $\begin{array}{c}0.000 \\
(0.316)\end{array}$ & $\begin{array}{c}0.005 \\
(0.012)^{* * * *}\end{array}$ & $\begin{array}{c}-0.002 \\
(0.000)^{* * * *}\end{array}$ & $\begin{array}{c}0.216 \\
(0.000)^{* * *}\end{array}$ & $\begin{array}{c}0.001 \\
(0.099) *\end{array}$ & $\begin{array}{c}0.000 \\
(0.000))^{* * * *}\end{array}$ & 288 & 0.824 & $\begin{array}{c}0.694 \\
(0.851)\end{array}$ & $\begin{array}{c}1.832 \\
(0.176)\end{array}$ & $\begin{array}{l}11.287 \\
(0.504)\end{array}$ \\
\hline POWER & $\begin{array}{l}-0.007 \\
(0.448)\end{array}$ & $\begin{array}{c}0.005 \\
(0.507)\end{array}$ & $\begin{array}{l}-0.013 \\
(0.528)\end{array}$ & $\begin{array}{c}0.001 \\
(0.109)\end{array}$ & $\begin{array}{c}0.000 \\
(0.980)\end{array}$ & $\begin{array}{c}0.020 \\
(0.000)^{* * *}\end{array}$ & $\begin{array}{c}-0.030 \\
(0.000))^{* * * *}\end{array}$ & $\begin{array}{c}0.000 \\
(0.906)\end{array}$ & $\begin{array}{c}0.000 \\
(0.056) *\end{array}$ & $\begin{array}{l}-0.003 \\
(0.819)\end{array}$ & $\begin{array}{c}0.071 \\
(0.000)^{* * *}\end{array}$ & $\begin{array}{c}0.000 \\
(0.875)\end{array}$ & $\begin{array}{c}0.000 \\
(0.250)\end{array}$ & 252 & 0.499 & $\begin{array}{c}0.647 \\
(0.874)\end{array}$ & $\begin{array}{c}1.437 \\
(0.231)\end{array}$ & $\begin{array}{l}7.909 \\
(0.792)\end{array}$ \\
\hline TEXTILE & $\begin{array}{l}-0.010 \\
(0.286) \\
\end{array}$ & $\begin{array}{c}0.015 \\
(0.087) *\end{array}$ & $\begin{array}{c}0.050 \\
(0.175)\end{array}$ & $\begin{array}{l}-0.001 \\
(0.303)\end{array}$ & $\mathrm{N} / \mathrm{A}$ & $\begin{array}{c}0.000 \\
(0.462) \\
\end{array}$ & $\begin{array}{c}0.003 \\
(0.740) \\
\end{array}$ & $\begin{array}{c}0.000 \\
(0.028)^{* *}\end{array}$ & $\begin{array}{c}0.000 \\
(0.375) \\
\end{array}$ & $\begin{array}{l}-0.005 \\
(0.483) \\
\end{array}$ & $\begin{array}{c}0.062 \\
(0.000)^{* * *}\end{array}$ & $\begin{array}{c}0.002 \\
(0.000)^{* * *}\end{array}$ & $\mathrm{~N} / \mathrm{A}$ & 156 & 0.641 & $\begin{array}{c}0.807 \\
(0.643) \\
\end{array}$ & $\begin{array}{c}0.448 \\
(0.503)\end{array}$ & $\begin{array}{l}10.407 \\
(0.406) \\
\end{array}$ \\
\hline PHARMA & $\begin{array}{c}0.011 \\
(0.819) \\
\end{array}$ & $\begin{array}{l}-0.030 \\
(0.367)\end{array}$ & $\begin{array}{c}0.051 \\
(0.279)\end{array}$ & $\begin{array}{l}-0.003 \\
(0.459)\end{array}$ & $\begin{array}{c}0.004 \\
(0.033)^{* *}\end{array}$ & $\begin{array}{l}-0.057 \\
(0.121)\end{array}$ & $\begin{array}{l}-0.017 \\
(0.526)\end{array}$ & $\begin{array}{c}0.000 \\
(0.967) \\
\end{array}$ & $\begin{array}{c}0.002 \\
(0.423) \\
\end{array}$ & $\begin{array}{c}0.005 \\
(0.539) \\
\end{array}$ & $\begin{array}{c}0.159 \\
(0.000) * * *\end{array}$ & $\mathrm{~N} / \mathrm{A}$ & N/A & 336 & 0.122 & $\begin{array}{c}0.852 \\
(0.680)\end{array}$ & $\begin{array}{c}0.341 \\
(0.559)\end{array}$ & $\begin{array}{l}9.279 \\
(0.506)\end{array}$ \\
\hline CONSGDS & $\begin{array}{c}-0.100 \\
(0.002)^{* * *}\end{array}$ & $\begin{array}{c}0.061 \\
(0.002)^{* * *}\end{array}$ & $\begin{array}{c}0.044 \\
(0.159)\end{array}$ & $\begin{array}{c}0.001 \\
(0.626)\end{array}$ & $\begin{array}{c}0.003 \\
(0.071)^{*}\end{array}$ & $\begin{array}{l}-0.004 \\
(0.920)\end{array}$ & $\begin{array}{l}-0.005 \\
(0.733)\end{array}$ & $\begin{array}{c}0.000 \\
(0.896)\end{array}$ & $\begin{array}{c}0.005 \\
(0.107)\end{array}$ & $\begin{array}{c}-0.027 \\
(0.031)^{* *}\end{array}$ & $\begin{array}{c}0.171 \\
(0.000)^{* * *}\end{array}$ & $\begin{array}{c}0.000 \\
(0.427)\end{array}$ & $\begin{array}{c}0.000 \\
(0.093) *\end{array}$ & 384 & 0.463 & $\begin{array}{c}1.022 \\
(0.438)\end{array}$ & $\begin{array}{c}0.000 \\
(0.991)\end{array}$ & $\begin{array}{l}8.760 \\
(0.723)\end{array}$ \\
\hline M-OTH & $\begin{array}{c}-0.053 \\
(0.000)^{* * *}\end{array}$ & $\begin{array}{c}0.025 \\
(0.000))^{* * *}\end{array}$ & $\begin{array}{c}0.001 \\
(0.956)\end{array}$ & $\begin{array}{c}0.000 \\
(0.679) \\
\end{array}$ & $\begin{array}{c}0.005 \\
(0.001)^{* * *}\end{array}$ & $\begin{array}{c}-0.070 \\
(0.001)^{* * *}\end{array}$ & $\begin{array}{l}-0.003 \\
(0.730) \\
\end{array}$ & $\begin{array}{c}0.000 \\
(0.927) \\
\end{array}$ & $\begin{array}{c}0.000 \\
(0.538)\end{array}$ & $\begin{array}{c}0.008 \\
(0.535)\end{array}$ & $\begin{array}{c}0.108 \\
(0.000)^{* * *}\end{array}$ & $\begin{array}{l}-0.001 \\
(0.245)\end{array}$ & $\begin{array}{c}0.000 \\
(0.093)^{*}\end{array}$ & 384 & 0.459 & $\begin{array}{c}1.257 \\
(0.168) \\
\end{array}$ & $\begin{array}{c}0.450 \\
(0.502)\end{array}$ & $\begin{array}{l}19.434 \\
(0.079) \\
\end{array}$ \\
\hline MEHH & $\begin{array}{l}-0.016 \\
(0.353) \\
\end{array}$ & $\begin{array}{l}-0.003 \\
(0.835) \\
\end{array}$ & $\begin{array}{l}-0.005 \\
(0.508)\end{array}$ & $\begin{array}{c}0.000 \\
(0.830) \\
\end{array}$ & $\begin{array}{c}0.002 \\
(0.045)^{* *}\end{array}$ & $\begin{array}{c}0.011 \\
(0.066)^{*}\end{array}$ & $\begin{array}{c}-0.027 \\
(0.049)^{* *}\end{array}$ & $\begin{array}{c}0.000 \\
(0.167)\end{array}$ & $\begin{array}{c}0.008 \\
(0.000) * * * *\end{array}$ & $\begin{array}{c}0.010 \\
(0.011)^{* *}\end{array}$ & $\begin{array}{l}-0.002 \\
(0.687) \\
\end{array}$ & $\begin{array}{c}0.000 \\
(0.817)\end{array}$ & $\begin{array}{c}0.000 \\
(0.133) \\
\end{array}$ & 216 & 0.359 & $\begin{array}{c}0.534 \\
(0.933)\end{array}$ & $\begin{array}{c}2.274 \\
(0.132) \\
\end{array}$ & $\begin{array}{c}9.218 \\
(0.684) \\
\end{array}$ \\
\hline S-OTHS & $\begin{array}{l}-0.018 \\
(0.279) \\
\end{array}$ & $\begin{array}{c}0.008 \\
(0.396)\end{array}$ & $\begin{array}{c}-0.006 \\
(0.002)^{* * *}\end{array}$ & $\begin{array}{c}0.001 \\
(0.395) \\
\end{array}$ & $\begin{array}{c}0.002 \\
(0.114) \\
\end{array}$ & $\begin{array}{c}0.001 \\
(0.717)\end{array}$ & $\begin{array}{l}-0.014 \\
(0.379) \\
\end{array}$ & $\begin{array}{c}0.000 \\
(0.531)\end{array}$ & $\begin{array}{c}0.000 \\
(0.909)\end{array}$ & $\begin{array}{c}0.061 \\
(0.000) * * *\end{array}$ & $\begin{array}{c}0.002 \\
(0.259) \\
\end{array}$ & $\begin{array}{c}0.000 \\
(0.122) \\
\end{array}$ & $\begin{array}{c}0.000 \\
(0.000) * * *\end{array}$ & 252 & 0.316 & $\begin{array}{c}1.494 \\
(0.085) \\
\end{array}$ & $\begin{array}{c}1.611 \\
(0.204) \\
\end{array}$ & $\begin{array}{l}23.513 \\
(0.024) \\
\end{array}$ \\
\hline CONSTR & $\begin{array}{c}-0.011 \\
(0.009)^{* * *}\end{array}$ & $\begin{array}{c}0.008 \\
(0.002)^{* * *}\end{array}$ & $\begin{array}{l}-0.020 \\
(0.060)^{*}\end{array}$ & $\begin{array}{l}-0.001 \\
(0.127)\end{array}$ & $\begin{array}{c}0.002 \\
(0.001)^{* * *}\end{array}$ & $\begin{array}{c}0.002 \\
(0.300)\end{array}$ & $\begin{array}{c}-0.010 \\
(0.005) * * *\end{array}$ & $\begin{array}{c}0.000 \\
(0.626)\end{array}$ & $\begin{array}{c}0.001 \\
(0.000))^{* * *}\end{array}$ & $\begin{array}{c}0.007 \\
(0.133)\end{array}$ & $\begin{array}{c}0.020 \\
(0.005)^{* * *}\end{array}$ & $\begin{array}{c}0.000 \\
(0.424)\end{array}$ & $\begin{array}{c}0.000 \\
(0.848)\end{array}$ & 264 & 0.313 & $\begin{array}{c}1.215 \\
(0.239)\end{array}$ & $\begin{array}{c}0.010 \\
(0.921)\end{array}$ & $\begin{array}{l}21.069 \\
(0.049)\end{array}$ \\
\hline LOGISTICS & $\begin{array}{c}0.010 \\
(0.372) \\
\end{array}$ & $\begin{array}{c}0.030 \\
(0.010)^{* * *}\end{array}$ & $\begin{array}{l}-0.002 \\
(0.947)\end{array}$ & $\begin{array}{c}0.001 \\
(0.279) \\
\end{array}$ & $\begin{array}{c}-0.003 \\
(0.000)^{* * *}\end{array}$ & $\begin{array}{c}0.002 \\
(0.710) \\
\end{array}$ & $\begin{array}{c}-0.044 \\
(0.000) * * *\end{array}$ & $\begin{array}{c}0.000 \\
(0.000)^{* * *}\end{array}$ & $\begin{array}{c}0.001 \\
(0.005) * * * \\
\end{array}$ & $\begin{array}{c}0.014 \\
(0.001)^{* * * *} \\
\end{array}$ & $\begin{array}{c}0.027 \\
(0.054) *\end{array}$ & $\begin{array}{c}0.003 \\
(0.000)^{* * * *}\end{array}$ & $\begin{array}{c}0.000 \\
(0.944) \\
\end{array}$ & 228 & 0.611 & $\begin{array}{c}0.902 \\
(0.576) \\
\end{array}$ & $\begin{array}{c}0.153 \\
(0.696) \\
\end{array}$ & $\begin{array}{l}15.415 \\
(0.220) \\
\end{array}$ \\
\hline ITTEL & $\begin{array}{l}-0.024 \\
(0.376)\end{array}$ & $\begin{array}{c}0.040 \\
(0.1264)\end{array}$ & $\begin{array}{c}0.152 \\
(0.000)^{* * *}\end{array}$ & $\begin{array}{l}-0.002 \\
(0.327)\end{array}$ & $\begin{array}{c}0.001 \\
(0.785) \\
\end{array}$ & $\begin{array}{c}-0.045 \\
(0.001)^{* * *}\end{array}$ & $\begin{array}{l}-0.047 \\
(0.065)^{*}\end{array}$ & $\begin{array}{c}0.000 \\
(0.807) \\
\end{array}$ & $\begin{array}{c}0.002 \\
(0.101) \\
\end{array}$ & $\begin{array}{c}0.005 \\
(0.611) \\
\end{array}$ & $\begin{array}{c}0.223 \\
(0.000)^{* * *}\end{array}$ & $\begin{array}{c}0.002 \\
(0.155) \\
\end{array}$ & $\begin{array}{c}0.000 \\
(0.481) \\
\end{array}$ & 312 & 0.550 & $\begin{array}{c}1.262 \\
(0.186)\end{array}$ & $\begin{array}{c}0.334 \\
(0.563) \\
\end{array}$ & $\begin{array}{l}27.815 \\
(0.006) \\
\end{array}$ \\
\hline BANKING & $\begin{array}{c}0.000 \\
(0.855)\end{array}$ & $\begin{array}{c}-0.005 \\
(0.000)^{* * *}\end{array}$ & $\begin{array}{c}-0.002 \\
(0.067)^{*}\end{array}$ & $\mathrm{~N} / \mathrm{A}$ & $\begin{array}{c}0.000 \\
(0.694)\end{array}$ & $\mathrm{N} / \mathrm{A}$ & $\begin{array}{c}0.002 \\
(0.021)^{* * *}\end{array}$ & $\begin{array}{c}0.005 \\
(0.000)^{* * *}\end{array}$ & $\begin{array}{c}0.000 \\
(0.019) * *\end{array}$ & $\begin{array}{l}-0.001 \\
(0.319)\end{array}$ & $\begin{array}{c}0.001 \\
(0.001)^{* * *}\end{array}$ & $\begin{array}{c}0.000 \\
(0.000)^{* * *}\end{array}$ & $\begin{array}{c}0.000 \\
(0.805)\end{array}$ & 384 & 0.444 & $\begin{array}{c}0.636 \\
(0.936)\end{array}$ & $\begin{array}{c}2.211 \\
(0.137)\end{array}$ & $\begin{array}{c}7.928 \\
(0.636)\end{array}$ \\
\hline FINSER & $\begin{array}{c}-0.040 \\
(0.003)^{* * * *}\end{array}$ & $\begin{array}{l}0.018 \\
(0.206)\end{array}$ & $\begin{array}{c}0.107 \\
(0.004) * * *\end{array}$ & $\mathrm{~N} / \mathrm{A}$ & $\begin{array}{l}0.000 \\
(0.879)\end{array}$ & $\mathrm{N} / \mathrm{A}$ & $\begin{array}{c}-0.022 \\
(0.004)^{* * *}\end{array}$ & $\begin{array}{l}0.000 \\
(0.178)\end{array}$ & $\begin{array}{c}0.000 \\
(0.989)\end{array}$ & $\begin{array}{l}-0.001 \\
(0.555)\end{array}$ & $\begin{array}{c}0.285 \\
(0.000) * * * *\end{array}$ & $\begin{array}{c}0.007 \\
(0.000)^{* * *}\end{array}$ & $\begin{array}{l}0.000 \\
(0.118)\end{array}$ & 492 & 0.533 & $\begin{array}{l}1.318 \\
(0.098)\end{array}$ & $\begin{array}{c}1.311 \\
(0.252)\end{array}$ & $\begin{array}{l}18.757 \\
(0.043)\end{array}$ \\
\hline
\end{tabular}

Note: Sector is the industrial sector to which a company belongs based on CMIE classification. Numbers within parentheses show number of firms in each sector. Regression coefficients are estimated using fixed effect model for AGRO sector and using pooled ordinary least squares for the remaining sectors. Dividends divided by total assets is the dependent variable. The independent variables are as follows. Tangibility is total assets minus current assets divided by total assets. BusRisk is the standard deviation of return on investment (ROI) (lagged three years). LgSales is the natural logarithm of sales in local currency. LgMCap is the natural logarithm of market capitalization in local currency. OpProfit is the earnings before interest and tax (EBIT) divided by total sales. DebtRatio is the long-term debt divided by total assets. IntCover is EBIT divided by interest. CurRatio is current assets divided by current liabilities. ROE is Net profit after tax (NPAT) divided by net worth. ROI is EBIT divided by capital employed (CE). P/B is Market Price Per share at the end of the year divided by book value per share for the year. CFPS is net cash flow from operating activities divided by number of equity shares outstanding. The $t$-statistics are given in parentheses. $* * *$ Significant at the 1 percent level,

** Significant at the 5 percent level \& * Significant at the 10 percent level. 


\section{References}

Abor, Joshua, and Godfred A. Bokpin. 2010. Investment Opportunities, Corporate Finance, and Dividend Payout Policy: Evidence from Emerging Markets. Studies in Economics and Finance 27: 180-94. [CrossRef]

Adkins, Lee C. 2010. Using Gretl for Principles of Econometric. Version 1.3131. Boston: Free Software Foundation.

Aivazian, Varouj, Laurence Booth, and Sean Cleary. 2003a. Dividend Policy and the Organization of Capital Markets. Journal of Multinational Financial Management 13: 101-21. [CrossRef]

Aivazian, Varouj, Laurence Booth, and Sean Cleary. 2003b. Do Emerging Market Firms Follow Different Dividend Policies from U.S. Firms? Journal of Financial Research 26: 371-87. [CrossRef]

Allen, Franklin, Antonio E. Bernardo, and Ivo Welch. 2000. A Theory of Dividends Based on Tax Clienteles. The Journal of Finance 55: 2499-536. [CrossRef]

Nizar Al-Malkawi, H. 2007. Determinants of Corporate Dividend Policy in Jordan: An Application of the Tobit Model. Journal of Economic and Administrative Sciences 23: 44-70. [CrossRef]

Al-Najjar, Basil. 2009. Dividend Behaviour and Smoothing New Evidence from Jordanian Panel Data. Studies in Economics and Finance 26: 182-97. [CrossRef]

Al-Najjar, Basil, and Erhan Kilincarslan. 2017. Corporate Dividend Decisions and Dividend Smoothing: New Evidence from an Empirical Study of Turkish Firms. International Journal of Managerial Finance 13: 1-38. [CrossRef]

Al-Shubiri, Faris Nasif. 2011. Determinants of Changes Dividend Behavior Policy: Evidence from the Amman Stock Exchange. Far East Journal of Psychology and Business 4: 1-15.

Auerbach, Alan J. 1982. Issues in the Measurement and Determinants of Business Saving. NBER Working Paper 1024. Cambridge: NBER.

Baiocchi, Giovanni, and Walter Distaso. 2003. GRETL: Econometric Software for the GNU Generation. Journal of Applied Econometrics 18: 105-10. [CrossRef]

Baker, H. Kent. 1988. The Relationship between Industry Classification and Dividend Policy. Southern Business Review 14: 1.

Baker, H. Kent, and Gary E. Powell. 2012. Dividend Policy in Indonesia: Survey Evidence from Executives. Journal of Asia Business Studies 6: 79-92. [CrossRef]

Baker, Malcolm, and Jeffrey Wurgler. 2004. Appearing and Disappearing Dividends: The Link to Catering Incentives. Journal of Financial Economics 73: 271-88. [CrossRef]

Baker, H. Kent, Gary E. Powell, and E. Theodore Veit. 2002. Revisiting the Dividend Puzzle. Do All of the Pieces Now Fit? Review of Financial Economics 11: 241-61. [CrossRef]

Baker, H. Kent, Samir Saadi, Shantanu Dutta, and Devinder Gandhi. 2007. The Perception of Dividends by Canadian Managers: New Survey Evidence. Edited by David Michayluk. International Journal of Managerial Finance 3: 70-91. [CrossRef]

Baker, H. Kent, Bin Chang, Shantanu Dutta, and Samir Saadi. 2013. Canadian Corporate Payout Policy. International Journal of Managerial Finance 9: 164-84. [CrossRef]

Benito, Andrew, and Garry Young. 2003. Hard Times or Great Expectations? Dividend Omissions and Dividend Cuts by UK Firms. Oxford Bulletin of Economics and Statistics 65: 531-55. [CrossRef]

Bhat, Ramesh, and Indra M. Pandey. 1994. Dividend Decision: A Study of Managers' Perception. Available online: http://search.proquest.com/openview/58cefb4c10c1cf9e9acab02494e5f48f/1?pq-origsite=gscholar\& cbl=1818288 (accessed on 15 February 2016).

Bhattacharya, Sudipto. 1979. Imperfect Information, Dividend Policy, and 'the Bird in the Hand' Fallacy. Bell Journal of Economics 10: 259-70. [CrossRef]

Bhole, Laxman M. 2000. Financing of the Private Corporate Sector: Trends, Issues, and Policies. Mumbai: Himalaya Publishing House.

Bhole, L. M., and Jitendra Mahakud. 2005. Trends and Determinants of Private Corporate Sector Savings in India. Economic and Political Weekly 40: 4234-50.

Black, Fischer. 1976. The New Dividend Puzzle. Journal of Portfolio Management 2: 5-8. [CrossRef]

Bostanci, Faruk, Eyup Kadioglu, and Guven Sayilgan. 2018. Determinants of Dividend Payout Decisions: A Dynamic Panel Data Analysis of Turkish Stock Market. International Journal of Financial Studies 6: 93. [CrossRef] 
Brav, Alon, John R. Graham, Campbell R. Harvey, and Roni Michaely. 2005. Payout Policy in the 21st Century. Journal of Financial Economics 77: 483-527. [CrossRef]

Brealey, Richard A., and Stewart C. Myers. 2002. Principles of Corporate Finance. Boston: Irwin McGraw-Hill Education.

Brockman, Paul, and Emre Unlu. 2009. Dividend Policy, Creditor Rights, and the Agency Costs of Debt. Journal of Financial Economics 92: 276-99. [CrossRef]

Chowdhury, Reza H., Min Maung, and Jenny Zhang. 2014. Information Content of Dividends: A Case of an Emerging Financial Market. Studies in Economics and Finance 31: 272-90. [CrossRef]

Cottrell, Allin, and Riccardo Jack Lucchetti. 2017. Gretl User's Guide: Gnu Regression, Econometrics and Time-Series Library. Boston: Free Software Foundation.

DeAngelo, Harry, Linda DeAngelo, and Douglas J. Skinner. 2004. Are Dividends Disappearing? Dividend Concentration and the Consolidation of Earnings. Journal of Financial Economics 72: 425-56. [CrossRef]

Dempsey, Stephen J., Gene Laber, and Michael S. Rozeff. 1993. Dividend Policies in Practice: Is There an Industry Effect? Quarterly Journal of Business and Economics 32: 3-13.

Denis, David J., and Igor Osobov. 2008. Why Do Firms Pay Dividends? International Evidence on the Determinants of Dividend Policy. Journal of Financial Economics 89: 62-82. [CrossRef]

Easterbrook, Frank H. 1984. Two Agency-Cost Explanations of Dividends. The American Economic Review 74: 650-59.

Von Eije, Henk, and William L. Megginson. 2008. Dividends and Share Repurchases in the European Union. Journal of Financial Economics 89: 347-74. [CrossRef]

Fama, Eugene F., and Kenneth R. French. 1999. The Corporate Cost of Capital and the Return on Corporate Investment. Journal of Finance 54: 1939-67. [CrossRef]

Fama, Eugene F., and Kenneth R. French. 2001. Disappearing Dividends: Changing Firm Characteristics or Lower Propensity to Pay. Journal of Financial Economics 60: 3-43. [CrossRef]

Farooq, Omar, and Imad Jabbouri. 2015. Cost of Debt and Dividend Policy: Evidence from the MENA Region. Journal of Applied Business Research 31: 1637-44. [CrossRef]

Ferris, Stephen P., Nilanjan Sen, and Ho Pei Yui. 2006. Are Fewer Firms Paying More Dividends? The International Evidence. Journal of Multinational Financial Management 16: 333-62. [CrossRef]

Foroghi, Dariush, Farzad Karimi, and Zahra Momeni. 2011. The Investigation Relationship of Dividend Behaviour and Likelihood of Paying Dividend with Financial Variables in Tehran Stock Exchange: Interdisciplinary. Journal of Contemporary Research in Business 3: 390-97.

Glen, Jack D., Yannis Karmokolias, Robert R. Miller, and Sanjay Shah. 1995. Dividend Policy and Behavior in Emerging Markets: To Pay or Not to Pay. IFC Discussion Papers. Washington: The World Bank.

Gordon, Myron J. 1963. Optimal Investment and Financing Policy. The Journal of Finance 18: 264-72.

Gujarati, Damodar N. 2009. Basic Econometrics. New Delhi: Tata McGraw Hill Education.

Gul, Ferdinand A. 1999. Government Share Ownership, Investment Opportunity Set and Corporate Policy Choices in China. Pacific-Basin Finance Journal 7: 157-72. [CrossRef]

Hausman, Jerry A. 1978. Specification Tests in Econometrics. Econometrica 46: 1251-71. [CrossRef]

Hill, R. Carter, William E. Griffiths, and Guay C. Lim. 2007. Principles of Econometrics, 3rd ed. Hoboken: Wiley.

Hsiao, Cheng. 1985. Benefits and limitations of panel data. Econometric Reviews 4: 121-74. [CrossRef]

Hsiao, Cheng. 1995. Panel Analysis for Metric Data. In Handbook of Statistical Modeling for the Social and Behavioral Sciences. Boston: Springer, pp. 361-400.

Hsiao, Cheng. 2003. Analysis of Panel Data, 2nd ed. Cambridge: Cambridge University Press.

Hsiao, Cheng, and Baohong Sun. 2000. To pool or not to pool panel data. Contributions to Economic Analysis 244: 181-98.

Imran, Kashif. 2011. Determinants of Dividend Payout Policy: A Case of Pakistan Engineering Sector. The Romanian Economic Journal 41: 47-59.

Jensen, Michael C. 1986. Agency Cost of Free Cash Flow, Corporate Finance, and Takeovers. The American Economic Review 76: 323-29.

Kevin, S. 1992. Dividend Policy: An Analysis of Some Determinants. Finance India 6: 253-59.

La Porta, Rafael, Florencio Lopez-de-Silanes, Andrei Shleifer, and Robert W. Vishny. 2000a. Investor Protection and Corporate Governance. Journal of Financial Economics 58: 3-27. [CrossRef]

La Porta, Rafael, Florencio Lopez-de-Silanes, Andrei Shleifer, and Robert W. Vishny. 2000b. Agency problems and dividend policies around the world. The Journal of Finance 55: 1-33. [CrossRef] 
Li, Wei, and Erik Lie. 2006. Dividend Changes and Catering Incentives. Journal of Financial Economics 80: $293-308$. [CrossRef]

Lintner, John. 1956. Distribution of Incomes of Corporations among Dividends, Retained Earnings, and Taxes. The'American Economic Review 49: 97-113.

Mahapatra, R. P., and P. K. Sahu. 1993. A Note on Determinants of Corporate Dividend Behaviour in India-An Econometric Analysis. Decision 20: 1-22.

Marsh, Terry A., and Robert C. Merton. 1987. Dividend Behavior for the Aggregate Stock Market. The Journal of Business 60: 1-40. [CrossRef]

Mehar, Ayub. 2005. Corporate Governance and Dividend Policy. Pakistan Economic and Social Review 43: 93-106.

Mehmood, Rashid, Ahmed Imran Hunjra, and Muhammad Irfan Chani. 2019. The Impact of Corporate Diversification and Financial Structure on Firm Performance: Evidence from South Asian Countries. Journal of Risk and Financial Management 12: 49. [CrossRef]

Michel, Allen. 1979. Industry Influence on Dividend Policy. Financial Management 8: 22-26. [CrossRef]

Miller, Merton, and Franco Modigliani. 1961. Dividend Policy, Growth, and the Valuation of Shares. The Journal of Business 34: 411-33. [CrossRef]

Miller, Merton H., and Kevin Rock. 1985. Dividend Policy under Asymmetric Information. The Journal of Finance 40: 1031-51. [CrossRef]

Mishra, Chandra Sekhar, and Vunyale Narender. 1996. Dividend Policy of SOEs in India: An Analysis. Finance India 10: 633-45.

Mitton, Todd. 2004. Corporate Governance and Dividend Policy in Emerging Markets. Emerging Markets Review 5: 409-26. [CrossRef]

Mohamed, Norhayati, Wee Shu Hui, Normah Hj Omar, Rashidah Abdul Rahman, Nor'azam Mastuki, Maz Ainy Abdul Azis, and Shazelina Zakaria. 2012. Empirical Analysis of Determinants of Dividend Payment: Profitability and Liquidity. Accounting Research Institute. Available online: https://www.researchgate.net/ profile/Mohamad_Zakaria2/publication/267220756_EMPIRICAL_ANALYSIS_OF_DETERMINANTS_OF_ DIVIDEND_PAYMENT_PROFITABILITY_AND_LIQUIDITY/links/54bce7080cf24e50e940b674.pdf (accessed on 17 May 2016).

Ooi, Joseph. 2001. Dividend Payout Characteristics of UK Property Companies. Journal of Real Estate Portfolio Management 7: 133-42.

Pandey, Indra M. 2003. Corporate Dividend Policy and Behaviour: The Malaysian Evidence. Asian Academy of Management Journal 8: 17-32.

Pandey, Indra M., and Ramesh Bhat. 2007. Dividend Behaviour of Indian Companies under Monetary Policy Restrictions. Managerial Finance 33: 14-25. [CrossRef]

Ramcharran, Harri. 2001. An Empirical Model of Dividend Policy in Emerging Equity Markets. Emerging Markets Quarterly 5: 39-49.

Reddy, Y. Subba, and Subhrendu Rath. 2005. Disappearing Dividends in Emerging Markets? Evidence from India. Emerging Markets Finance and Trade 41: 58-82. [CrossRef]

Renneboog, Luc, and Grzegorz Trojanowski. 2007. Control Structures and Payout Policy. Managerial Finance 33: 43-64. [CrossRef]

Ross, Stephen A. 1977. The Determination of Financial Structure: The Incentive-Signalling Approach. The Bell Journal of Economics 8: 23. [CrossRef]

Sawicki, Julia. 2003. An Investigation into the Dividend Policy of Firms in East Asia. Working Paper. Singapore: Nanyang Technological University School of Business Anyang Avenue.

Sawicki, Julia. 2009. Corporate governance and dividend policy in Southeast Asia pre- and post-crisis. European Journal of Finance 15: 211-30. [CrossRef]

Scott, David F., and John D. Martin. 1975. Industry Influence on Financial Structure. Financial Management 4: 67-73. [CrossRef]

Setia-Atmaja, Lukas. 2010. Dividend and Debt Policies of Family Controlled Firms: The Impact of Board Independence. International Journal of Managerial Finance 6: 128-42. [CrossRef]

Solomon, Ezra. 1963. The Theory of Financial Management. New York: Colombia University Press.

Subhash Kamat, Manoj, and Manasvi M. Kamat. 2013. Economic Reforms, Determinants and Stability of Dividends in a Dynamic Setting. Edited by Arif Khurshed. Journal of Asia Business Studies 7: 5-30. [CrossRef] 
Tangjitprom, Nopphon. 2013. Propensity to Pay Dividends and Catering Incentives in Thailand. Studies in Economics and Finance 30: 45-55. [CrossRef]

Walter, James E. 1963. Dividend Policy: Its Influence on the Value of the Enterprise. The Journal of Finance 18: 280-91. [CrossRef]

Yarram, Subba Reddy. 2015. Corporate Governance Ratings and the Dividend Payout Decisions of Australian Corporate Firms. International Journal of Managerial Finance 11: 162-78. [CrossRef]

Yusof, Yusniliyana, and Suhaiza Ismail. 2016. Determinants of Dividend Policy of Public Listed Companies in Malaysia. Review of International Business and Strategy 26: 88-99. [CrossRef]

(C) 2019 by the authors. Licensee MDPI, Basel, Switzerland. This article is an open access article distributed under the terms and conditions of the Creative Commons Attribution (CC BY) license (http://creativecommons.org/licenses/by/4.0/). 